Worldviews and Intergenerational Altruism:

A Comparison of Turkish People

Living in Turkey and Germany

K. Ali Akkemik / Mehmet Bulut

Marcus Dittrich / Koray Göksal

Kristina Leipold / Masao Ogaki

CESIFO WORKING PAPER NO. 6404

CATEGORY 13: BEHAVIOURAL ECONOMICS

MARCH 2017

An electronic version of the paper may be downloaded

- from the SSRN website:

- from the RePEc website:

- from the CESifo website:

WwW.SSRN.com

www.RePEc.org

www.CESifo-group.org/wp 


\title{
Worldviews and Intergenerational Altruism: A Comparison of Turkish People Living in Turkey and Germany
}

\begin{abstract}
In this paper, we examine and compare the impact of cultural differences on intergenerational altruism in Turkish people living in Turkey and in Germany, using the anthropological concept of worldview. Data were gathered from four surveys: nationwide surveys in Turkey and Germany, an online survey of Turkish people living in Germany, and a survey conducted as an experiment in a mosque attended by Turkish people in Germany. We find striking differences in parenting attitudes between Turkish people living in Turkey and those who live in Germany. Turkish people living in Germany tend to resemble German people in their parenting attitudes. We also find that differences in confidence attached to worldview beliefs, differences in religiosity, and the subjective probabilities attached to worldview beliefs (such as "All humans evolved from another living organism”) between Turkish people living in Turkey and those in Germany have statistically significant explanatory power for these differences in parenting attitudes.
\end{abstract}

JEL-Codes: Z100, Z120, D640.

Keywords: intergenerational altruism, worldviews, religion, tough love, spoiling love.

\author{
K. Ali Akkemik \\ Kadir Has University \\ Istanbul / Turkey \\ ali.akkemik@khas.edu.tr \\ Marcus Dittrich \\ Deggendorf Institute of Technology \\ Deggendorf / Germany \\ marcus.dittrich@th-deg.de \\ Kristina Leipold \\ Dresden University of Technology \\ Dresden / Germany \\ k.leipold@gmx.de
}

\author{
Mehmet Bulut \\ Istanbul Sabahattin Zaim University \\ Istanbul / Turkey \\ mehmetbulut05@gmail.com \\ Koray Göksal \\ Yildirim Beyazit University \\ Ankara / Turkey \\ kgoksal@ybu.edu.tr \\ Masao Ogaki \\ Keio University \\ Tokyo / Japan \\ mogaki@econ.keio.ac.jp
}

This research was supported by Scientific and Technological Research Council of Turkey, TUBITAK (Project No. 110K319), Keio University Department of Economics Kenkyu Kyoiku Shikin, and JSPS KAKENHI Grant Number 25285063. 


\section{Introduction}

Economic models of intergenerational altruism from various perspectives have been developed (e.g., Barro 1974, Becker 1974, Andreoni 1989). Recent models of intergenerational altruism (e.g., Akabayashi 2006, Doepke and Zilibotti 2008, 2014, and Bhatt and Ogaki 2012) have suggested that parents intentionally affect children's endogenous preferences. These models can be viewed as part of the literature on cultural transmission of preferences that started with Bisin and Verdier (2001). A new normative economic analysis approach can be taken to these models by adding considerations of virtue ethics - such as the Pareto principle-to welfarism, as shown by Bhatt, Ogaki, and Yaguchi $(2015,2016)$.

We use a survey question about parenting attitudes that can be interpreted as "spoiling love" and "tough love" as Bhatt and Ogaki (2012) describe them. In this model, the child has an endogenous time discount factor that depends on childhood consumption, determined by parental transfers to the child. The parent believes that the child should attain a certain level of patience, measured by the time discount factor. If this level of patience is high, then the parent shows tough love. However, the parent is tempted to spoil the child because the altruistic parent obtains higher utility when the child gains higher utility from her childhood consumption. If the level of patience is low, then the parent has spoiling love.

If two groups of people have different attitudes regarding spoiling and tough love, the difference may be caused by cultural differences (see, e.g., Guiso, Sapenza, and Zingales 2006 for a survey of cultural economics). We use the anthropological concept of worldview to analyze cultural differences. We define worldview as "the foundational cognitive, affective, and evaluative assumptions and frameworks a group of people makes about the nature of reality which they use to order their lives" (Hiebert 2008: p.25).

Comparing Turkey and Germany is interesting in two respects. First, German culture is shaped mainly by Christian beliefs (both Catholic and Protestant), while Turkish culture is shaped mainly by Islamic beliefs. Second, there is a large Turkish community living in Germany amounting to around 4 percent of the population. The Turkish population of Germany is made up of the "guest workers" who migrated to Germany in the 1960s and 1970s and their descendants. The extent to which cultural differences affect differences in economic outcomes in Turkey and Germany may hold important policy lessons. A comparison of Turkish immigrants in Germany with their peers in the homeland may shed light on various issues related to integration with German society.

The rest of the paper is organized as follows. Section 2 explains the model, as well as the data and variables used in the analyses. Section 3 compares the Turkish and German surveys and describes group-level differences. Section 4 presents the results, and the section 5 concludes. 


\section{Data and Model}

In this section, we explain the data and variables used in the econometric model. The dependent variable of the econometric model, which is explained in detail below, is a discrete choice variable. Therefore, we run probit regressions.

\subsection{Data}

To measure the impact of sociodemographic variables, religiosity, time preferences, and worldviews on tough love and spoiling love attitudes, we use data obtained from four surveys in Germany and Turkey. Some of the questions in the survey were from the Preference and Life Satisfaction Survey conducted by the Osaka University $21{ }^{\text {st }}$ Century Center of Excellence Program (see Kubota et al. 2013). The surveys included questions about sociodemographic conditions, household structure, allocation of time, economic conditions, time preferences, risk tolerance, charitable donations, parental attitudes towards children, religious affiliation, religiosity, worldviews, and hypothetical questions. For the most part, the surveys are identical but the German survey included additional questions about immigrants. All respondents were at least 18 years old.

Our data on Turkish people in Turkey and Germany cover diverse areas of these two countries, even though they are not representative. For example, our nationwide data for Germany used an online survey. Online surveys are not representative unless they are supplemented by other surveys because there is a sample selection bias that arises when only people with Internet connections are sampled. However, as Benjamin, Heffetz, Kimball and Szembrot (2014) show, online surveys can include a diverse range of people. Regression results for these data can be useful for learning what factors affect people's attitudes and are important in their economic behavior.

Our nationwide survey in Turkey was conducted between July and September 2011. The survey was funded by TUBITAK (project no. 110K319). ${ }^{1}$ Data were collected from twelve provinces from twelve NUTS-1 regions. We first chose the three most populated provinces in Turkey: Istanbul, Izmir, and Ankara from the three regions to which they belong. Then, one province was randomly chosen from the remaining nine regions. These provinces were Balikesir, Batman, Bursa, Diyarbakir, Kayseri, Konya, Mersin, Samsun, and Trabzon.

We collected 3,180 survey questionnaire forms, of which 1,717 of them were usable for econometric analysis. 69 percent of the respondents were male. The religious affiliations of the respondents are as follows: Sunni Muslim: 83.3 percent, Alevi Muslim: 8.0 percent, Other Muslim: 2.5 percent, Christian: 0.4 percent, others and no affiliation: 5.2 percent.

The data for Germany were obtained from two online surveys conducted in September 2011 and November 2011 and a survey conducted as an experiment at a mosque attended by

\footnotetext{
${ }^{1}$ Ethical Review Board approval for this project was obtained from the Atatürk Education and Research Hospital in Ankara on June 30, 2011.
} 
Turkish people in October $2010 .^{2}$ The online survey data were collected by a professional research company on our instructions. Participants were recruited from an online panel of approximately 90,000 people living in Germany. Email invitations were sent to 4,291 potential participants, and 1,019 responded to the first online survey in September 2011. In this survey, the four Turkish respondents were included in our dataset. The second online survey in October 2010 targeted only Turkish people, and had a total of 139 respondents. The respondents in the two online surveys were aged between 18 and 66 years. The proportion of participants in each of the 16 federal states of Germany was designed to be proportional to the number of responses to those in the first online survey. In total, 143 respondents to the two online surveys answered "Turkish" in response to the question "Which language did you mainly speak at home when you were under six years old?" For the purpose of this research, they were identified as "Turkish people in Germany" in these two surveys. We also used data from an experiment at a mosque attended by Turkish people, when 26 people responded. Twenty-four people answered "Turkish" to the language question above. One answered "Kurdish" and another "Arabic." We also identify these 26 subjects as "Turkish people in Germany." Overall, the total number of "Turkish people in Germany" surveyed was 169.

\subsection{Variables}

\subsubsection{Dependent Variable}

Our dependent variable is a discrete choice variable obtained from a hypothetical question in the survey. The dependent variable is constructed as a dummy variable taking the value of 1 if the response indicates tough love or spoiling love, and 0 otherwise. The question is as follows.

Suppose that you have a two-year old child who has high fever and is in pain. The child's doctor, whom you trust, tells you that both the fever and pain are harmless. He can give you a medicine that cures the sickness but slightly weakens the child's immune system when the child becomes 50 years old. What would you do? (Circle ONE number)

1. I would give the medicine to the child if the sickness is known to last for one day.

2. I would give the medicine to the child if the sickness is known to last for two days.

3. I would give the medicine to the child if the sickness is known to last for one week.

4. I would give the medicine to the child if the sickness is known to last for one month.

5. I would not give the medicine to the child.

We interpret answer 5 in this question as tough love and answer 1 as spoiling love. ${ }^{3}$

\footnotetext{
${ }^{2}$ Each respondent was paid four euros for participation in the survey.

${ }^{3}$ We realize that answers to this question can be affected by medical systems and trust in medical systems in different countries. Using a hypothetical situation in which the respondent trusts the doctor, we minimize this effect.
} 


\subsubsection{Independent Variables}

Sociodemographic variables: The respondents were categorized with respect to age, education, and income (annual household income inclusive of bonuses). Education and income groups were differentiated slightly between Turkey and Germany (see the appendix for the categories of age, education, and income in Turkish and German surveys). There is a dummy variable that takes the value of 1 if the respondent has a child and 0 otherwise, and a gender dummy variable taking the value of 1 if the respondent is male and 0 otherwise.

The greater similarity of Turkish people in Germany to Germans rather than to their counterparts in Turkey may be attributable to the influence of their life in Germany, place of birth, or place of education on their beliefs and attitudes. For some Turkish immigrants in Germany, it may be true that their values and behavior resembled those of Germans from the beginning and did not change during their stay. On the other hand, it is likely that they underwent gradual cultural assimilation-i.e., their worldviews, values, and behavior were Turkish when they arrived in Germany and gradually become more German with longer residence and over successive generations. Therefore, we added a variable to measure how length of stay in Germany affects values and behavior. This was the number of years the respondent spent in Germany divided by his or her age. ${ }^{4}$

Religiosity: To measure religiosity, we use self-reported subjective evaluations of the respondents. For this purpose, we asked whether the statement "I am deeply religious" holds true for the respondent. The respondent marks a number on a scale from 1 to 5,1 indicating total disagreement and 5 indicating total agreement. We interpret answer 5 as deeply religious, and accordingly created a dummy taking the value of 1 for this answer and 0 otherwise.

Time preferences: To measure time preferences (impatience and debt aversion), we use two questions that are shown in the appendix. Measurement of time preferences is explained by Kubota et al. (2013).

Worldviews: In the surveys, we used a set of questions to measure worldviews. Specifically, we chose the answers to the following questions.

1. I hope to live as simple a life as possible.

2. I will never be robbed.

3. I always keep my promises.

4. I know much about politics.

5. I have a good memory.

6. I believe that what is written in science books is right.

7. If, because of an accident, you suffered pain, there is meaning in that pain such as personality development.

8. If, because of an accident, people suffered pain, there is meaning in that pain such as personality development.

9. I believe human beings evolved from other living things.

10. All living things are created by God.

\footnotetext{
${ }^{4}$ As an alternative, we also used the number of years spent in Germany only and found that the results did not change qualitatively.
} 
11. The afterlife exists.

12. Heaven exists.

13. Hell exists.

14. A person may be reincarnated as another person.

15. Spiritual beings such as God, Buddha, gods, or angels exist.

16. When you conduct good behavior and no one else knows about it, you are watched by God or other spiritual beings.

17. When you conduct good behavior and no one else knows about it, you will be rewarded by God or other spiritual beings.

18. When you conduct bad behavior and no one else knows about it, you are watched by God or other spiritual beings.

19. When you conduct bad behavior and no one else knows about it, you will be punished by God or other spiritual beings.

The worldview questions above are measured using a scale from 0 to 100 , progressing in multiples of 10 . The answer 0 indicates "I totally disagree" and 100 "I totally agree" with the statement.

Confidence in worldviews: Kubota et al. (2013) showed that parents' confidence in their worldviews is strongly related to intergenerational altruism. They argued that confidence in worldviews affects the decision not to medicate the child and to allow the child to suffer. To account for this effect, we constructed two confidence variables, namely spiritually directed confidence and nonspiritually directed confidence.

Confidence variables are constructed using a set of survey questions. For the spiritually directed and nonspiritually directed confidence variables, we use the following eight questions.

(i) Heaven exists.

(ii) Hell exists.

(iii) When you conduct good behavior and no one else knows about it, you are monitored by God or other spiritual beings.

(iv) When you conduct good behavior and no one else knows about it, you will be rewarded by God or other spiritual beings.

(v) When you conduct bad behavior and no one else knows about it, you are monitored by God or other spiritual beings.

(vi) When you conduct bad behavior and no one else knows about it, you will be punished by God or other spiritual beings.

(vii) A person may be reincarnated as another person.

(viii) I believe human beings evolved from other living things

A scale from 0 to 100, progressing in multiples of 10, is used for these questions. On this scale, 0 means "I totally disagree" and 100 means "I totally agree." To calculate spiritually directed confidence, we assign a score of 1 for each question if the respondent has chosen 90 or 100 to questions (i) to (vii) and 0 or 10 to question (viii), and 0 otherwise. These answers indicate strong confidence about spiritual matters. We then add the scores and calculate the total score for spiritually directed confidence, ranging from 0 to 8 . To calculate nonspiritually directed confidence, we assign a score of 1 if the respondent has chosen 0 or 10 to questions (i) to (vii) and 90 or 100 to question (viii) and zero points otherwise. We then add the points and calculate the total score for spiritually directed confidence, ranging from 0 to 8 . 
Summary statistics for all dependent and independent variables are shown in Table 1.

\section{Comparison of Surveys in Turkey and Germany}

\subsection{Turkish Migrants in Germany}

While the earliest records of Turkish people coming to Germany were in the early $1800 \mathrm{~s}$, the large-scale migration of Turks to what was then West Germany began in the 1960s. During the economic boom after World War II, there were more jobs than unemployed people, so the German labor market needed workers. ${ }^{5}$ The German government reacted by recruiting workers from Turkey, among other countries, by signing an official labor trade contract between the governments of the two countries. Both sides expected that the move of these guest workers would be only temporary, which may explain why no steps were taken to fully integrate them. However, many stayed in Germany permanently. According to official statistics, the German Federal Statistical Office (Destatis), 20 percent of the German population in 2012 was of migrant background. It is estimated that about a fifth of this group, about 3-4 million people, are of Turkish origin.

Integration of the Turkish people into German society has been an important issue for Germany. Religious and cultural differences are important constraints in this sense. Early immigrants and the second generation have been virtually all of Muslim background, mostly Sunni Islam. Their integration into the Christian-dominated German society would eventually encounter religious differences. It is well known that the first-generation immigrants (guest workers) and their reunited families had an educational background much lower than the German average, but subsequent generations were educated in Germany and were integrated into German society to a greater extent. Exposed to German cultural values, Turkish migrants of subsequent generations were more receptive than the first generation. On the other hand, it is well known that preservation of the Turkish identity and Islamic values in the family are also given importance. For instance, Diehl and Schnell (2006) showed that distinctive cultural habits and the Turkish identity, in general, were often used by second-generation Turkish migrants to compensate for their disadvantaged social status. This disadvantaged social status results from the low participation of Turkish migrants in the German education system and poor German language skills (Söhn and Özcan, 2006).

Cultural and religious differences between Turkish migrants and Germans are manifested in various aspects of social life. For instance, Diehl et al. (2009) examined whether the Islamic background of Turkish migrants and religiosity make a difference in gender equality and gender role attitudes in sharing of housework among couples. They found that traditional values of Turkish migrants, which are less gender egalitarian (i.e., allocate more housework to women) than those of Germans, were sustained by religious commitment.

\footnotetext{
${ }^{5}$ For a narrative of this immigration process, see Martin (1991) and Şen (2003).
} 


\subsection{Comparison of Tough Love found in the Turkish and German Surveys}

In this section, we focus on group-level differences between the respondents in Germany and those in Turkey. We are specifically interested in the differences between Turkish people in Turkey and Turkish people in Germany.

The frequency distributions for the fever question for all respondents in the surveys in Germany (including both Germans and originally non-German people) and Turkey are presented in Figure 1. We measure tough love as a response of 5; i.e., "I would not give the medicine," and spoiling love with a response of 1; i.e., "I would give the medicine if the sickness is known to last for one day." There are stark differences between Germany and Turkey in the frequency distributions of the answers. Seventy-one percent of the respondents in Turkey selected answer 1, whereas only 11 percent in Germany did so. In other words, tough love parents make up a very small proportion of the sample in Turkey compared with those in Germany. On the other hand, only 8 percent of the respondents in Turkey chose answer 5 , compared with 50 percent in Germany. This means that half of the respondents would not give the medicine in Germany whereas only 8 percent in Turkey would do so. These are tough love respondents. The number of respondents showing tough love in Germany is greater than that in Turkey. Answers 2, 3, and 4 imply attitudes of temptation. These parents amount to about 21 percent of the sample in Turkey and about 39 percent in Germany. These results point to an interesting comparison: the majority of the respondents do not demonstrate tough love in Turkey, while the majority of the respondents in Germany do.

Figure 1 also shows the frequency distributions of the answers given to the hypothetical fever question by Turkish people living in Germany. Unlike their counterparts in Turkey, most Turkish respondents living in Germany exhibit tough love. Parents who do not show tough love make up a small proportion only. Therefore, their parenting attitude toward a young child resembles that of the German people rather than that of Turkish people in Turkey.

\subsection{Comparison of Turkish Respondents in Germany and in Turkey}

Interesting results arise when Turkish people living in Germany are compared with those in Turkey. Before presenting these differences, we asked the Turkish people in Germany about the length of time they had spent there. Time spent in Germany may be used as a rough indicator of exposure to German culture. Some respondents had lived in Germany since birth and others had immigrated to Germany after spending time in the home country. Figure 2 shows length of residence in Germany: 25 percent of the respondents had lived in Germany for 3140 years, another 20 percent for $23-30$ years, and 14 percent for $41-55$ years. We assume that the longer they stayed in Germany, the greater their exposure to the German culture. If the German culture had any influence on their economic behavior, this can be observed in the answers given to the hypothetical question about tough love. Below, we compare the frequency distributions of Turkish people in Germany with those of Turkish people living in Turkey. For convenience, we split the sample of Turkish respondents in Germany into five subgroups: 
those who have lived in Germany for (i) 15 years or less, (ii) 16-22 years, (iii) 23-30 years, (iv) 31-40 years, and (v) 41 years or more.

Table 2 shows the frequencies of responses from Turkish people with respect to the number of years spent in Germany. The table shows that the peak frequency for tough love responses is from those who have lived there for 31-40 years (22), followed by 23-30 years (18) and 41-55 years (12). While there are fewer spoiling love parents, their length of time in Germany differs little from those who show tough love. Table 2 shows that the peak frequency of tough love responses (answers 2 and 3) is 31-40 years (28), followed by 23-30 years (22), and 41-55 years (15). In all subgroups, tough love parents predominate. Of all respondents who have lived in Germany for more than 23 years, 55 percent demonstrate tough love. The corresponding figures for those who have lived in Germany for 16-22 years and 15 years or less are 48 percent and 38 percent, respectively. Therefore, we conclude that tough love behavior is mostly observed among Turkish immigrants who have spent more than 23 years in Germany. We argue that those who have lived there for 41 years or longer count as the first generation. An important characteristic of these first-generation immigrants is that they were educated in Turkey in their native language. The other subgroups may have more exposure to German cultural values.

Table 3 presents summary statistics for all worldview questions in the surveys of seven subsamples: (i) Turkish respondents in the Turkish national survey, (ii) all respondents in the German national survey, and Turkish respondents in the German survey who have lived in Germany for (iii) 15 years or less, (iv) 16-22 years, (v) 23-30 years, (vi) 31-40 years, and (vii) 41 years or more. These immigrant subgroups differ from each other and from the Turkish sample in their responses to the questions about belief in God, the afterlife, Heaven, Hell and reincarnation, whether there is meaning in life for suffering for oneself or for others, and whether God is watching and rewarding/punishing good/bad deeds. The mean values of these questions exhibit some discrepancy between the German and Turkish samples and across subgroups among the Turkish respondents in the German surveys. For the worldview questions about belief in God, the afterlife and Hell, respondents in Turkey have high averages while the averages for the Turkish respondents in Germany are somewhat lower. In addition, the differences in the mean values of the worldview beliefs that good deeds are watched and rewarded and bad deeds are watched and punished by God are smaller between the Turkish respondents and their Turkish counterparts in Germany than between native Turkish and native German respondents.

An important difference between Turkish immigrants in Germany and respondents in Turkey is observed in their responses to the question about evolution. The average value for the question about whether the respondent believes in evolution (62 out of 100) in Germany is far higher than that of that in Turkey (12). On average, respondents in Turkey strongly disbelieve the proposition that human beings evolved from other living things. A possibility is that Turkish immigrants in Germany have adopted a view of evolution that is quite different from respondents in Turkey. Various factors may influence this difference. One factor may be the differences in education systems between Turkey and in Germany. Taking this as an indicator 
of a secular worldview, one may argue that in general German respondents and Turkish immigrants in Germany are far more secular than respondents in Turkey.

Turkish immigrants in Germany also show similar scores to native Germans and unlike those of respondents in Turkey in terms of their view of reincarnation. A higher proportion of Turkish respondents in Germany (an average 52 out of 100) believe that a person may be reincarnated, in contrast to those in Turkey (17). Respondents in Turkey strongly disbelieve that a person may be reincarnated, while such disbelief among Turkish immigrants in Germany is quite weak.

The responses to the questions about whether there is a meaning in suffering for oneself and for others, such as personality development, demonstrate a stark difference between the Turkish and German surveys. Respondents in Turkey seem to have a more positive attitude toward suffering (with average scores of about 87-88 out of 100) while the Turkish respondents in Germany incline towards the negative view (average scores about 45-46).

Another difference between the Turkish and German surveys is observed in the questions "I want to live as simple a life as possible" where the average value for people in Turkey is higher than that of Turkish people in Germany. For the worldview questions "I will never be robbed," "I know much about politics," and "I have a good memory," the mean values for the Turkish respondents in Germany are higher.

There are also differences in worldview across groups among the Turkish respondents in Germany. Turkish respondents who have stayed in Germany for more than 22 years generally score as high as respondents in Turkey on worldview beliefs about the existence of an afterlife, Heaven, Hell. Moreover, people who have lived in Germany for 15 years or less have lower average scores for worldview beliefs about God watching and rewarding/punishing good/bad deeds. These statistics reveal an important characteristic of the Turkish respondents in the German survey. Those respondents who had stayed in Germany for less than 23 years are quite different from the respondents in Turkey and other Turkish respondents in Germany. For the worldview questions about suffering, those who had stayed in Germany for less than 23 years have a more negative view of suffering. Furthermore, Turkish respondents who had stayed in Germany for 15 years or less have higher average scores for worldview beliefs about evolution and reincarnation.

The comparison between Turkish people in Germany or Turkey with the German respondents with regards to spiritually and nonspiritually directed confidence is noteworthy. The frequency distributions of the confidence variables are presented in Figures 3 and 4. Turkish respondents in Germany are similar to those in Turkey and score higher for spiritually directed confidence. In contrast, German respondents have far lower scores. This means that Turkish respondents in both Turkey and Germany are quite confident about their worldviews regarding spiritual matters, but German respondents are quite unconfident.

The nonspiritually directed confidence frequency distributions shown in Figure 4 also exhibit similarity between Turkish respondents in Turkey and in Germany. Scores between 0 and 1 are more frequent for both groups. The most common score in Turkey is 0 (90 percent). 
For Turkish respondents in Germany, the most common score is 0 (53 percent), followed by scores of 1 (19 percent) and 4 (11 percent). However, the most common score for German respondents is 1 with a frequency of 20 percent, followed by scores of 0 (19 percent) and 8 (16 percent). Therefore, while Turkish respondents in both Germany and Turkey are unconfident about nonspiritual matters, German respondents seem slightly more confident.

Large differences between Turkish people in Germany and Turkish people in Turkey are observed in the following worldview questions:

1. If, because of an accident, you suffered pain, there is meaning in that pain such as personality development.

2. If, because of an accident, people suffered pain, there is meaning in that pain such as personality development.

3. I believe human beings evolved from other living things.

4. All living things are created by God.

5. I want to live as simple a life as possible.

6. A person may be reincarnated as another person.

Compared with their counterparts in Turkey, Turkish respondents in Germany seem to have adopted a relatively secular worldview while maintaining their religious beliefs regarding the existence of God and afterlife. This observation is further strengthened by the question about their belief in evolution. The mean value for the question about the worldview belief that human beings evolved from other living things for the German survey overall is 76 out of 100. The mean value for the Turkish respondents in Germany (65) is closer to the native German score and far exceeds the mean for respondents in Turkey (12). Similarly, Turkish respondents in Germany more closely resemble the German respondents in their belief that a person may be reincarnated. The mean value of these worldview questions for Turkish respondents in Germany (52) is closer to the mean value for German respondents (34) than to their Turkish counterparts in Turkey (16).

\section{Empirical Findings}

In this section, we present the results of the probit analyses and Blinder-Oaxaca decomposition. We ran three regressions for each, including one of the three worldview variables. The dependent variable is tough love. In each regression, we added a dummy variable taking the value of 1 if the observation belongs to the German sample and 0 otherwise. Below, we report the marginal effects of the regressions. In addition to the probit model estimates, we use the nonlinear Blinder-Oaxaca decomposition technique to examine the contributions of the variables used in the regressions to individual-level differences in parental discipline between Turkish people living in Turkey and those living in Germany.

\subsection{Probit Regression Results}

The results of the regression where the dependent variable takes the value of 1 if the answer is "I would not give the medicine" and 0 otherwise are shown in Table 4 . We interpret this an- 
swer to indicate spoiling love. The results presented in the table are marginal effects. Model (1) is our baseline, and includes sociodemographic variables, religiosity, and confidence variables.

The results show that the coefficient of the ratio of years spent in Germany to age is positive and statistically significant, at least at the 1 percent level. The coefficient of the age variable is negative and statistically significant at the 5 percent level. Therefore, people who spend more of their lives in Germany and older people are less likely to show spoiling love. The religiosity variable is positive and significant, at least at the 1 percent level; i.e., the more religious the Turkish respondents are, the more they are likely to show tough love. In other words, increasing religiosity increases the likelihood of a spoiling love attitude. The dummy variables for having children, education, and gender are all statistically insignificant. Both time preference variables, impatience and debt aversion are statistically significant at the 10 percent level. The coefficient of the impatience variable is negative, while that of the debt aversion variable is positive. These findings imply that respondents who are more impatient are less likely to exhibit spoiling love behavior, whereas those with high debt aversion are more likely to do so. The negative coefficient of the impatience variable confirms the hypothesis of the tough love model that if the parent is patient, then the child will also grow to be patient.

Two confidence variables are included in the probit regressions. The nonspiritually directed confidence variable is negative but statistically insignificant in all regressions. The spiritually directed confidence variable is significant at the 10 percent level with a positive sign. This implies that people with higher levels of spiritually directed confidence are more likely to show spoiling love.

We now focus our attention on worldviews and confidence in worldviews. Models (2), (3), and (4) include the worldview variables as well as those in the baseline model (1). The coefficients of the three worldview variables are significant at the 1 percent level. The coefficient of the evolution worldview variable (constructed from the survey question about the degree to which respondents believe that human beings evolved from other living things) is negative and statistically significant at the 1 percent level. This finding means that respondents who believe more strongly in evolution are less likely to show spoiling towards their children.

The coefficient of the reincarnation worldview variable (constructed from the survey question about the degree to which respondents believe that a person may be reincarnated as another person) is statistically significant and negative at the 1 percent level. Therefore, the stronger believers in reincarnation are less likely to show their children spoiling love.

The coefficient of the worldview variable about living a simple life (constructed from survey question about wanting to live as simple a life as possible) is statistically significant and positive at the 1 percent level. This finding implies that respondents who want to live a simple life are more likely to show their children spoiling love. 


\subsection{Blinder-Oaxaca Decomposition Results}

Below, we analyze the contributions of the variables to the differences in expressions of parental love between Turkish people in Turkey and those in Germany using Blinder-Oaxaca decomposition. For our probit regressions, we use the nonlinear Blinder-Oaxaca decomposition method. Technical details of this method can be found in Fairlie (2005). Oaxaca and Ransom (1999) showed that using dummy variables leads to a problem in the Blinder-Oaxaca decomposition such that the contributions of the sets of dummy variables to the differences in the dependent variable are not invariant with respect to the selection of the reference group that is left out when dummy variables are determined. Accordingly, we do not include the two dummy variables (gender and having children) used in the probit regressions in the decomposition analysis. Because these variables are insignificant in spoiling love regressions, we do not expect this specification to cause any problem for the decomposition.

The Blinder-Oaxaca decomposition results for differences in spoiling love (The answer "I would give the medicine to the child if the sickness is known to last for one day") are reported in Table 5. The total contributions of the variables range from 17 to 26 percent of the total variance explained. The most important variables to explain the difference in spoiling behavior between Turkish respondents in Turkey and those in Germany are, in order of importance, nonspiritually directed confidence, religiosity, and the worldview variables. The coefficient of nonspiritually directed confidence is positive and statistically significant at the 5 percent level. Nonspiritually directed confidence has the highest contribution of all variables, explaining about 10-11 percent of the difference in spoiling behavior between Turkish respondents in Turkey and those in Germany. The contribution of religiosity is also positive and significant at the 1 percent level. Religiosity explains about 5-6 percent of the difference. The coefficients of all other sociodemographic variables are insignificant.

The coefficients of the worldview variables about beliefs in evolution and reincarnation, as well as the desire to live a simple life are all statistically significant and positive at the 1 percent level. Belief in evolution explains about 8 percent of the difference in spoiling behavior between Turkish people in Germany and those in Turkey. Belief in reincarnation explains about 4 percent of the difference, and desire for a simple life explains about 2 percent of this difference.

\section{Conclusion}

In our data, Turkish people in Turkey and those in Germany have strikingly different attitudes to spoiling love. The majority of this difference can be explained by differences between these two groups in terms of (1) nonspiritually directed confidence, (2) worldview beliefs such as evolution, reincarnation, and a desire to live a simple life, and (3) religiosity.

In our regression results, when a person is more religious, then he/she is more likely to show spoiling love. A possible interpretation is that the person will pray for an absence of immune system problems after the child grows up. When a person has more nonspiritually 
directed confidence, then the person is less likely to show spoiling love. A possible interpretation is that the person is less likely to believe in prayer, so is more likely to think that he/she should not give medicine. A person who assigns a higher subjective probability to evolution is less likely to show spoiling love. A possible interpretation is that the person is less likely to believe in prayer, so is less likely to be willing to give medicine. A person who assigns a higher subjective probability to reincarnation is less likely to show spoiling love. Such a person may put less weight on pain in this life when making decisions. A person who agrees more strongly with the statement "I want to live a simple life" is more likely to show spoiling love, perhaps because the person values everyday life more.

\section{References}

Akabayashi, H. (2006). An Equilibrium Model of Child Maltreatment. Journal of Economic Dynamics and Control, 30, 993-1025

Andreoni, J. (1989). Giving with Impure Altruism: Applications to Charity and Ricardian Equivalence. Journal of Political Economy, 97, 1447-1458

Barro, R.J. (1974). Are Government Bonds Net Wealth? Journal of Political Economy, 82, 1095-1117

Becker, G. (1974). A Theory of Social Interactions. Journal of Political Economy, 82, 10631093

Benjamin, D.J., O. Heffetz, M.S. Kimall, and N. Szembrot (2014). Beyond Happiness and Satisfaction: Toward Well-Being Indices Based on Stated Preference. American Economic Review 104, 2698-2735

Bhatt, V. and M. Ogaki (2012). Tough Love and Intergenerational Altruism. International Economic Review, 53, 791-814

Bhatt, V., M. Ogaki, and Y. Yaguchi (2015). Normative Behavioural Economics Based on Unconditional Love and Moral Virtue. Japanese Economic Review 66, 226-246

Bhatt, V., M. Ogaki, and Y. Yaguchi (2016). Introducing Moral Virtue Ethics into Normative Economics for Models with Endogenous Preferences. Paper presented at Macroeconomics Workshop at Tel Aviv University, March 2016

Bisin, A. and T. Verdier (2001). The Economics of Cultural Transmission and the Dynamics of Preferences. Journal of Economic Theory, 97, 298-319

Bolton, G.E. and A. Ockenfels (2000). A Theory of Equity, Reciprocity, and Competition. American Economic Review, 90, 166-193

Diehl, C., M. Koenig, and K. Ruckdeschel (2009). Religiosity and Gender Equality: Comparing Natives and Muslim Migrants in Germany. Ethnic and Racial Studies, 32(2), 278-301

Diehl, C. and R. Schnell (2006). "Reactive Ethnicity" or "Assimilation"? Statements, Arguments, and First Empirical Evidence for Labor Migrants in Germany. International Migration Review, 40(4), 786-816

Doepke, M. and F. Zilibotti (2008). Occupational Choice and the Spirit of Capitalism. Quarterly Journal of Economics, 123, 747-793 
Doepke, M. and F. Zilibotti (2014). Parenting with Style: Altruism and Paternalism in Intergenerational Preference Transmission. NBER Working Paper Series, Working Paper 20214

Fairlie, R.W. (2005). An Extension of the Blinder-Oaxaca Decomposition Technique to Logit and Probit Models. Journal of Economic and Social Measurement, 30, 305-316

Fehr, E. and K.M. Schmidt (1999). A Theory of Fairness, Competition and Cooperation. Quarterly Journal of Economics, 114 (3), 817-868

Guiso, L., P. Sapienza, and L. Zingales (2006). Does Culture Affect Economic Outcomes? Journal of Economic Perspectives, 20, 23-48

Hao, L., V.J. Hotz, and G.Z. Jin (2008). Games Parents and Adolescents Play: Risky Behaviors, Parental Reputation, and Strategic Transfers. Economic Journal, 118, 515-555

Hiebert, P.G. (2008). Transforming Worldviews: An Anthropological Understanding of How People Change. Grand Rapids, Michigan: Baker Publishing

Kubota, K., A. Kamesaka, M. Ogaki, and F. Ohtake (2013). Cultures, Worldviews, and Intergenerational Altruism. Paper presented at the European Regional Science Association 2013 Congress

Lee, S. Y., Kim, B.Y., H.U. Kwon, Lim, M. Ogaki, and F. Ohtake (2013). Altruistic Economic Behavior and Implicit Worldviews. Paper presented at the $7^{\text {th }}$ Annual Meeting of Association of Behavioral Economics and Finance

Martin, Philip L. (1991). The Unfinished Story: Turkish Labour Migration to Western Europe: With Special Reference to the Federal Republic of Germany, International Labor Organization

Oaxaca, R.L. and M.R. Ransom (1999). Identification in Detailed Wage Decompositions. Review of Economics and Statistics, 81(1), 154-157

Şen, F. (2003). The Historical Situation of Turkish Migrants in Germany. Immigrants and Minorities, 22(2-3), 208-227

Söhn, J. and V. Özcan (2006). The Educational Attainment of Turkish Migrants in Germany. Turkish Studies, 7(1), 101-124

Tobacyk, J. and G. Milford (1983). Belief in Paranormal Phenomena: Assessment Instrument Development and Implications for Personality Functioning. Journal of Personality and Social Psychology, 44, 1029-1037

Weinberg, B.A. (2001). An Incentive Model of the Effect of Parental Income on Children. Journal of Political Economy, 109, 266-280

Yamane, S., H. Yoneda, and Y. Tsutsui (2012). Homo Economicus vs. Human Being: Outcomes of Irrationality. Institute of Social and Economic Research, Osaka University, Discussion Paper No. 844 


\section{Appendix}

\section{Categories of Age, Education, and Income}

Age categories in both Turkey and Germany surveys are as follows: (i) 18-23, (ii) 24-29, (iii) 30-35, (iv) 36-41, (v) 42-47, (vi) 48-53, (vii) 54-59, (viii) 60-69, and (ix) 70 and above.

Education categories in both surveys are as follows: (i) primary education (grade school in Germany survey), (ii) high school or equivalent not graduated, (iii) high school graduate, (iv) some college (no degree), (v) 2-year college (associate's degree in the German survey), (vi) 4year university graduate - bachelor's degree, (vii) non-degree graduate school, (viii) graduate degree - MS, MA, MBA, etc., and (ix) doctoral degree - DVM, PhD, DDS, etc.

Income categories in the Turkish survey are as follows: (i) none, (ii) TRY 10,000 or less, (iii) TRY 10,000 to less than TRY 20,000, (iv) TRY 20,000 to less than TRY 40,000, (v) TRY 40,000 to less than TRY 60,000, (vi) TRY 60,000 to less than TRY 80,000, (vii) TRY 80,000 to less than TRY 100,000, (viii) TRY 100,000 to less than TRY 120,000, (ix) TRY 120,000 to less than TRY 140,000, and (x) TRY 140,000 or more. TRY refers to the Turkish Lira.

Income categories in the German survey are as follows: (i) less than $€ 10,000$, (ii) $€ 10,000$ to less than $€ 20,000$, (iii) $€ 20,000$ to less than $€ 40,000$, (iv) $€ 40,000$ to less than $€ 60,000$, (v) $€ 60,000$ to less than $€ 80,000$, (vi) $€ 80,000$ to less than $€ 100,000$, (vii) $€ 100,000$ to less than $€ 120,000$, (viii) $€ 120,000$ to less than $€ 140,000$, (ix) $€ 140,000$ to less than $€ 160,000$, (x) $€ 160,000$ to less than $€ 180,000$, (xi) $€ 180,000$ to less than $€ 200,000$, and (xii) $€ 200,000$ or more.

\section{Debt Aversion and Impatience}

To measure impatience, the following question was used in the Turkish survey. In the German survey, the currency unit was changed from Turkish Lira (TRY) to Euros.

\begin{tabular}{|c|c|c|c|c|c|}
\hline \multirow{2}{*}{$\begin{array}{l}\text { Option "A" } \\
\text { Receiving } \\
\text { today }\end{array}$} & \multirow{2}{*}{ or } & \multirow{2}{*}{$\begin{array}{l}\text { Option "B" } \\
\text { Receiving in } \\
7 \text { days }\end{array}$} & \multirow{2}{*}{$\begin{array}{l}\text { Includes an annual } \\
\text { interest rate of }\end{array}$} & \multicolumn{2}{|c|}{$\begin{array}{l}\text { Which ONE do you prefer? } \\
\text { (X ONE Box For EACH Row }\end{array}$} \\
\hline & & & & Option "A" & Option "B" \\
\hline TRY 100.00 & & TRY 99.81 & $-10 \%$ & ........... $1 \square$ & $2 \square$ \\
\hline TRY 100.00 & & TRY 100.00 & $0 \%$ & ..........1 $\square$ & $2 \square$ \\
\hline TRY 100.00 & & TRY 100.19 & $10 \%$ & ..........1 $\square$ & $2 \square$ \\
\hline TRY 100.00 & & TRY 100.38 & $20 \%$ & ........1 $\square$ & $2 \square$ \\
\hline TRY 100.00 & & TRY 100.96 & $50 \%$ & ..........1 $\square$ & $2 \square$ \\
\hline TRY 100.00 & & TRY 101.91 & $100 \% \ldots \ldots \ldots . . .$. & ........1 & $2 \square$ \\
\hline TRY 100.00 & & TRY 103.83 & $200 \%$ & .......... $1 \square$ & $2 \square$ \\
\hline TRY 100.00 & & TRY 105.74 & $300 \%$ & ..........1 $\square$ & $2 \square$ \\
\hline
\end{tabular}


For debt aversion, the following question was used.

Suppose that you have the option to pay TRY 10,000 in one month or pay a different amount in thirteen months. Compare the amounts and timing in Option "A" with Option "B" and indicate which amount you would prefer to pay for all 8 choices.

\begin{tabular}{|c|c|c|c|c|c|}
\hline Option "A" & & & & $\begin{array}{l}\text { Which ON } \\
\text { (X ONE Bo }\end{array}$ & $\begin{array}{l}\text { you prefer? } \\
\text { EACH Row }\end{array}$ \\
\hline $\begin{array}{l}\text { Paying in one } \\
\text { month }\end{array}$ & or & $\begin{array}{l}\text { Paying in } 13 \\
\text { months }\end{array}$ & $\begin{array}{l}\text { Includes an annual } \\
\text { interest rate of: }\end{array}$ & Option "A" & Option "B" \\
\hline TRY 10,000 & & TRY 9,500 & $-5 \% \ldots \ldots \ldots$ & $\ldots \ldots \ldots . .1 \square$ & $2 \square$ \\
\hline TRY 10,000 & & TRY 10,000 & $0 \% \ldots \ldots \ldots \ldots$ & .......1 $\square$ & $2 \square$ \\
\hline TRY 10,000 & & TRY 10,010 & $0.1 \% \ldots \ldots$ & $\ldots .1 \square$ & $2 \square$ \\
\hline TRY 10,000 & & TRY 10,050 & $0.5 \% \ldots \ldots \ldots \ldots . . .$. & .......1 $\square$ & $2 \square$ \\
\hline TRY 10,000 & & TRY 10,100 & $1 \% \ldots \ldots \ldots \ldots \ldots$ & .......1 $\square$ & $2 \square$ \\
\hline TRY 10,000 & & TRY 10,200 & $2 \% \ldots \ldots \ldots \ldots$ & $\ldots .1 \square$ & $2 \square$ \\
\hline TRY 10,000 & & TRY 10,600 & $6 \% \ldots \ldots \ldots \ldots$ & $\ldots .1 \square$ & $2 \square$ \\
\hline TRY 10,000 & & TRY 11,000 & $10 \%$ & ...........1 & $2 \square$ \\
\hline
\end{tabular}


Table 1: Descriptive statistics for Turkish respondents in Germany and Turkey

\begin{tabular}{|c|c|c|c|c|c|c|c|c|}
\hline & Mean & Std. dev. & Min & Max & Mean & Std. dev. & Min & Max \\
\hline & \multicolumn{4}{|c|}{ TURKEY } & \multicolumn{4}{|c|}{ GERMANY } \\
\hline \multicolumn{9}{|l|}{ Dependent variable } \\
\hline Spoiling love & 0.71 & 0 & 1 & 0.46 & 0.12 & 0 & 1 & 0.33 \\
\hline \multicolumn{9}{|l|}{ Time preferences } \\
\hline Impatience & -0.36 & -2.51 & 6.26 & 2.27 & -0.19 & -6.26 & 6.26 & 2.14 \\
\hline Debt aversion & -0.20 & -4.68 & 9.92 & 5.06 & 0.12 & -4.68 & 9.92 & 3.01 \\
\hline \multicolumn{9}{|l|}{ Sociodemographic variables } \\
\hline Religious & 0.27 & 0.44 & 0 & 1 & 0.41 & 0.49 & 0 & 1 \\
\hline Gender $($ male $=1)$ & 0.69 & 0.31 & 0 & 1 & 0.54 & 0.50 & 1 & 1 \\
\hline Age & 3.98 & 2.24 & 1 & 9 & 4.07 & 2.35 & 1 & 9 \\
\hline Education (in groups) & 3.80 & 2.26 & 1 & 9 & 4.89 & 2.35 & 1 & 9 \\
\hline Children ( 1 = have children $)$ & 0.61 & 0.49 & 0 & 1 & 0.56 & 0.50 & 0 & 1 \\
\hline Income (in groups) & 2.17 & 1.94 & 0 & 12 & 4.97 & 3.53 & 0 & 12 \\
\hline \multicolumn{9}{|l|}{ Confidence variables } \\
\hline Spiritually directed confidence & 7.65 & 1.24 & 0 & 8 & 5.79 & 2.61 & 0 & 8 \\
\hline Nonspiritually directed confidence & 0.14 & 0.62 & 0 & 8 & 1.78 & 2.66 & 0 & 8 \\
\hline \multicolumn{9}{|l|}{ Worldview variables } \\
\hline I want to live as simple a life as possible. & 4.08 & 1.21 & 1 & 5 & 3.38 & 1.34 & 1 & 5 \\
\hline I will never be robbed. & 2.70 & 1.23 & 1 & 5 & 3.23 & 1.17 & 1 & 5 \\
\hline I always keep my promises. & 3.98 & 1.06 & 1 & 5 & 4.25 & 0.72 & 1 & 5 \\
\hline I know much about politics. & 2.99 & 1.23 & 1 & 5 & 3.51 & 1.14 & 1 & 5 \\
\hline I have a good memory. & 3.62 & 1.09 & 1 & 5 & 4.11 & 0.87 & 1 & 5 \\
\hline $\begin{array}{l}\text { I believe that what is written in science books is } \\
\text { right. }\end{array}$ & 3.38 & 1.09 & 1 & 5 & 3.51 & 0.94 & 1 & 5 \\
\hline $\begin{array}{l}\text { If, because of an accident, you suffered pain, there is } \\
\text { meaning in that pain such as personality } \\
\text { development. }\end{array}$ & 88.31 & 24.64 & 0 & 100 & 44.94 & 33.44 & 0 & 100 \\
\hline $\begin{array}{l}\text { If, because of an accident, people suffered pain, } \\
\text { there is meaning in that pain such as personality } \\
\text { development. }\end{array}$ & 87.02 & 25.98 & 0 & 100 & 43.85 & 33.24 & 0 & 100 \\
\hline $\begin{array}{l}\text { I believe human beings evolved from other living } \\
\text { things. }\end{array}$ & 12.07 & 30.78 & 0 & 100 & 61.81 & 36.51 & 0 & 100 \\
\hline All living things are created by God. & 98.56 & 9.75 & 0 & 100 & 65.49 & 37.02 & 0 & 100 \\
\hline The afterlife exists. & 97.96 & 11.33 & 0 & 100 & 82.58 & 37.03 & 0 & 100 \\
\hline Heaven exists. & 98.25 & 10.30 & 0 & 100 & 92.36 & 25.45 & 0 & 100 \\
\hline Hell exists. & 98.10 & 11.13 & 0 & 100 & 83.54 & 36.09 & 0 & 100 \\
\hline A person may be reincarnated as another person. & 16.48 & 35.31 & 0 & 100 & 52.22 & 48.87 & 0 & 100 \\
\hline $\begin{array}{l}\text { Spiritual beings such as God, Buddha, gods, or } \\
\text { angels exist. }\end{array}$ & 98.67 & 9.30 & 0 & 100 & 78.53 & 39.82 & 0 & 100 \\
\hline $\begin{array}{l}\text { When you conduct good behavior and no one else } \\
\text { knows about it, you are watched by God or other } \\
\text { spiritual beings. }\end{array}$ & 98.41 & 10.14 & 0 & 100 & 86.03 & 33.33 & 0 & 100 \\
\hline $\begin{array}{l}\text { When you conduct good behavior and no one else } \\
\text { knows about it, you will be rewarded by God or } \\
\text { other spiritual beings. }\end{array}$ & 96.08 & 15.19 & 0 & 100 & 86.14 & 33.36 & 0 & 100 \\
\hline $\begin{array}{l}\text { When you conduct bad behavior and no one else } \\
\text { knows about it, you are watched by God or other } \\
\text { spiritual beings. }\end{array}$ & 98.11 & 11.48 & 0 & 100 & 87.76 & 31.42 & 0 & 100 \\
\hline $\begin{array}{l}\text { When you conduct bad behavior and no one else } \\
\text { knows about it, you will be punished by God or } \\
\text { other spiritual beings. }\end{array}$ & 94.60 & 17.57 & 0 & 100 & 89.17 & 29.31 & 0 & 100 \\
\hline
\end{tabular}


Table 2. Frequencies of answers to the fever question by Turkish respondents in Germany with respect to years spent in Germany

\begin{tabular}{lccccc}
\hline & 15 years or less & $16-22$ years & $23-30$ years & $31-40$ years & 41 years or more \\
\hline Give, one day & 0 & 1 & 8 & 7 & 3 \\
Give, two days & 4 & 3 & 2 & 1 & 4 \\
Give, one week & 8 & 5 & 3 & 6 & 3 \\
Give, one month & 4 & 5 & 2 & 4 & 5 \\
Not give & 10 & 13 & 18 & 22 & 18 \\
\hline Total & 26 & 27 & 33 & 40 & 33 \\
\hline & & Percentages & & \\
\hline Give, one day & $0 \%$ & $4 \%$ & $24 \%$ & $18 \%$ & $9 \%$ \\
Give, two days & $15 \%$ & $11 \%$ & $6 \%$ & $3 \%$ & $12 \%$ \\
Give, one week & $31 \%$ & $19 \%$ & $9 \%$ & $15 \%$ & $15 \%$ \\
Give, one month & $15 \%$ & $19 \%$ & $6 \%$ & $10 \%$ & $55 \%$ \\
Not give & $38 \%$ & $48 \%$ & $55 \%$ & $55 \%$ & $100 \%$ \\
\hline Give, one day & $100 \%$ & $100 \%$ & $100 \%$ & $100 \%$ & \\
\hline
\end{tabular}


Table 3. Summary statistics for worldview questions

\begin{tabular}{|c|c|c|c|c|c|c|c|c|c|c|c|c|c|c|c|c|c|c|c|c|c|}
\hline & \multirow{2}{*}{\multicolumn{3}{|c|}{ Turkey }} & \multirow{2}{*}{\multicolumn{3}{|c|}{$\begin{array}{l}\text { Germany (all } \\
\text { respondents) }\end{array}$}} & \multicolumn{15}{|c|}{ Turkish respondents in Germany survey (number of years spent in Germany) } \\
\hline & & & & & & & \multicolumn{3}{|c|}{15 years or less } & \multicolumn{3}{|c|}{$16-22$ years } & \multicolumn{3}{|c|}{ 23-30 years } & \multicolumn{3}{|c|}{$31-40$ years } & \multicolumn{3}{|c|}{41 years or more } \\
\hline & Mean & Med & SD & Mean & Med & SD & Mean & Med & SD & Mean & Med & SD & Mean & Med & SD & Mean & Med & SD & Mean & Med & $\mathrm{SD}$ \\
\hline $\begin{array}{l}\text { I hope to live as } \\
\text { simple a life as } \\
\text { possible. }\end{array}$ & 4.1 & 5 & 1.2 & 3.5 & 4 & 1.5 & 3.2 & 4 & 1.4 & 3.1 & 4 & 1.2 & 3.4 & 4 & 1.4 & 3.4 & 4 & 1.4 & 3.7 & 4 & 1.2 \\
\hline $\begin{array}{l}\text { I will never be } \\
\text { robbed. }\end{array}$ & 2.7 & 3 & 1.2 & 3.6 & 3 & 1.4 & 3.5 & 3 & 1.1 & 3.2 & 3 & 1.3 & 3.3 & 3 & 1.0 & 3.1 & 3 & 1.2 & 3.2 & 3 & 1.3 \\
\hline $\begin{array}{l}\text { I always keep my } \\
\text { promises. }\end{array}$ & 4.0 & 4 & 1.1 & 4.3 & 4 & 0.8 & 4.2 & 4 & 0.5 & 4.4 & 4 & 0.6 & 4.1 & 4 & 1.0 & 4.2 & 4 & 0.6 & 4.4 & 5 & 0.6 \\
\hline $\begin{array}{l}\text { I know much about } \\
\text { politics. }\end{array}$ & 3.0 & 3 & 1.2 & 3.6 & 4 & 1.2 & 3.4 & 4 & 1.2 & 3.5 & 4 & 1.2 & 3.4 & 4 & 1.1 & 3.5 & 4 & 1.2 & 3.6 & 4 & 1.1 \\
\hline $\begin{array}{l}\text { I have a good } \\
\text { memory. }\end{array}$ & 3.6 & 4 & 1.1 & 4.2 & 4 & 0.9 & 4.1 & 4 & 1.0 & 4.1 & 4 & 0.8 & 3.9 & 4 & 1.0 & 4.2 & 4 & 0.7 & 4.1 & 4 & 1.0 \\
\hline $\begin{array}{l}\text { I believe that what } \\
\text { is written in science } \\
\text { books is right. }\end{array}$ & 3.4 & 3 & 1.1 & 3.6 & 4 & 1.0 & 3.5 & 4 & 1.0 & 3.8 & 4 & 0.9 & 3.2 & 3 & 0.8 & 3.6 & 4 & 1.0 & 3.5 & 4 & 0.9 \\
\hline $\begin{array}{l}\text { If, because of an } \\
\text { accident, you } \\
\text { suffered pain, there } \\
\text { is meaning in that } \\
\text { pain such as } \\
\text { personality } \\
\text { development. }\end{array}$ & 88.3 & 100 & 24.6 & 43.8 & 50 & 33.4 & 38.1 & 50 & 36.0 & 37.1 & 45 & 32.9 & 46.1 & 50 & 30.4 & 45.5 & 40 & 35.0 & 47.3 & 60 & 33.9 \\
\hline $\begin{array}{l}\text { If, because of an } \\
\text { accident, people } \\
\text { suffered pain, there } \\
\text { is meaning in that } \\
\text { pain such as } \\
\text { personality } \\
\text { development. }\end{array}$ & 87.0 & 100 & 26.0 & 42.9 & 50 & 33.2 & 39.4 & 50 & 33.4 & 36.1 & 35 & 32.5 & 48.5 & 50 & 31.1 & 42.9 & 40 & 36.5 & 41.8 & 50 & 31.7 \\
\hline $\begin{array}{l}\text { I believe human } \\
\text { beings evolved } \\
\text { from other living } \\
\text { things. }\end{array}$ & 12.1 & 0 & 30.8 & 65.4 & 70 & 36.5 & 70.0 & 50 & 37.8 & 67.5 & 80 & 37.1 & 57.0 & 70 & 37.5 & 66.7 & 70 & 33.0 & 58.8 & 70 & 39.0 \\
\hline $\begin{array}{l}\text { All living things } \\
\text { are created by God. }\end{array}$ & 98.6 & 100 & 9.8 & 63.6 & 80 & 37.0 & 50.0 & 100 & 38.7 & 51.0 & 50 & 42.5 & 71.8 & 80 & 31.5 & 66.2 & 70 & 36.7 & 69.1 & 90 & 35.0 \\
\hline The afterlife exists. & 98.0 & 100 & 11.3 & 81.3 & 100 & 37.0 & 64.4 & 100 & 41.0 & 59.3 & 100 & 49.3 & 94.2 & 100 & 23.1 & 91.2 & 100 & 27.5 & 85.5 & 100 & 35.0 \\
\hline Heaven exists. & 98.3 & 100 & 10.3 & 91.4 & 100 & 25.5 & 86.2 & 100 & 25.9 & 95.0 & 100 & 21.2 & 94.1 & 100 & 23.4 & 91.0 & 100 & 27.8 & 91.0 & 100 & 27.5 \\
\hline
\end{tabular}




\begin{tabular}{|c|c|c|c|c|c|c|c|c|c|c|c|c|c|c|c|c|c|c|c|c|c|}
\hline Hell exists. & 98.1 & 100 & 11.1 & 82.1 & 100 & 36.1 & 71.5 & 100 & 35.9 & 68.3 & 100 & 46.2 & 90.9 & 100 & 28.7 & 79.3 & 100 & 39.6 & 90.3 & 100 & 29.5 \\
\hline $\begin{array}{l}\text { A person may be } \\
\text { reincarnated as } \\
\text { another person. }\end{array}$ & 16.5 & 0 & 35.3 & 55.6 & 10 & 48.9 & 71.5 & 100 & 47.9 & 40.0 & 5 & 49.3 & 60.0 & 100 & 49.2 & 57.3 & 100 & 48.9 & 41.3 & 10 & 48.8 \\
\hline $\begin{array}{l}\text { Spiritual beings } \\
\text { such as God, } \\
\text { Buddha, gods, or } \\
\text { angels exist. }\end{array}$ & 98.7 & 100 & 9.3 & 75.9 & 100 & 39.9 & 52.5 & 100 & 44.8 & 59.7 & 100 & 49.0 & 91.2 & 100 & 28.3 & 80.5 & 100 & 37.9 & 86.1 & 100 & 33.5 \\
\hline $\begin{array}{l}\text { When you conduct } \\
\text { good behavior and } \\
\text { no one else knows } \\
\text { about it, you are } \\
\text { monitored by God } \\
\text { or other spiritual } \\
\text { beings. }\end{array}$ & 98.4 & 100 & 10.1 & 83.4 & 100 & 33.3 & 53.3 & 100 & 42.6 & 86.0 & 100 & 34.2 & 93.9 & 100 & 23.8 & 84.1 & 100 & 35.4 & 88.8 & 100 & 30.2 \\
\hline $\begin{array}{l}\text { When you conduct } \\
\text { good behavior and } \\
\text { no one else knows } \\
\text { about it, you will } \\
\text { be rewarded by } \\
\text { God or other } \\
\text { spiritual beings. }\end{array}$ & 96.1 & 100 & 15.2 & 84.4 & 100 & 33.4 & 52.5 & 100 & 43.0 & 90.0 & 100 & 30.0 & 88.1 & 100 & 31.6 & 88.3 & 100 & 31.9 & 88.4 & 100 & 31.1 \\
\hline $\begin{array}{l}\text { When you conduct } \\
\text { bad behavior and } \\
\text { no one else knows } \\
\text { about it, you are } \\
\text { monitored by God } \\
\text { or other spiritual } \\
\text { beings. }\end{array}$ & 98.1 & 100 & 11.5 & 86.3 & 100 & 31.4 & 68.3 & 100 & 36.8 & 86.0 & 100 & 34.2 & 93.9 & 100 & 23.8 & 86.3 & 100 & 33.4 & 88.8 & 100 & 30.2 \\
\hline $\begin{array}{l}\text { When you conduct } \\
\text { bad behavior and } \\
\text { no one else knows } \\
\text { about it, you will } \\
\text { be punished by } \\
\text { God or other } \\
\text { spiritual beings. }\end{array}$ & 94.6 & 100 & 17.6 & 88.2 & 100 & 29.3 & 76.7 & 100 & 32.2 & 94.7 & 100 & 22.9 & 93.9 & 100 & 23.8 & 85.0 & 100 & 33.6 & 88.8 & 100 & 30.2 \\
\hline
\end{tabular}

Note: Med.: Median, S.D.: standard deviation 
Table 4. Results of probit analysis (dependent variable: spoiling love)

\begin{tabular}{|c|c|c|c|c|c|c|c|c|c|c|c|c|}
\hline & $(1)$ & & & $(2)$ & & & (3) & & & (4) & & \\
\hline Religious & 0.057 & $(0.013)$ & *** & 0.047 & $(0.013)$ & *** & 0.048 & $(0.013)$ & *** & 0.046 & $(0.013)$ & *** \\
\hline Male dummy variable & 0.026 & $(0.048)$ & & 0.019 & $(0.048)$ & & 0.019 & $(0.048)$ & & 0.022 & $(0.048)$ & \\
\hline Age & -0.002 & $(0.001)$ & ** & -0.002 & $(0.001)$ & $* *$ & -0.002 & $(0.001)$ & $* *$ & -0.003 & $(0.001)$ & ** \\
\hline Education & 0.003 & $(0.007)$ & & 0.001 & $(0.007)$ & & 0.001 & $(0.007)$ & & 0.001 & $(0.007)$ & \\
\hline Children dummy variable & -0.013 & $(0.017)$ & & -0.014 & $(0.017)$ & & -0.015 & $(0.017)$ & & -0.013 & $(0.017)$ & \\
\hline Impatience & -0.012 & $(0.007)$ & * & -0.012 & $(0.007)$ & * & -0.012 & $(0.007)$ & * & -0.009 & $(0.007)$ & \\
\hline Debt aversion & 0.006 & $(0.003)$ & * & 0.006 & $(0.003)$ & * & 0.006 & $(0.003)$ & * & 0.006 & $(0.003)$ & * \\
\hline Income & -0.006 & $(0.007)$ & & -0.004 & $(0.007)$ & & -0.006 & $(0.007)$ & & -0.005 & $(0.007)$ & \\
\hline Years spent in Germany to age ratio & -0.550 & $(0.074)$ & $* * *$ & -0.486 & $(0.075)$ & *** & -0.501 & $(0.075)$ & $* * *$ & -0.548 & $(0.074)$ & *** \\
\hline Spiritually directed confidence & -0.016 & $(0.018)$ & & -0.023 & $(0.018)$ & & -0.017 & $(0.018)$ & & -0.015 & $(0.018)$ & \\
\hline Nonspiritually directed confidence & -0.059 & $(0.024)$ & $* * *$ & -0.056 & $(0.024)$ & ** & -0.061 & $(0.024)$ & $* * *$ & -0.057 & $(0.024)$ & ** \\
\hline Evolution & & & & -0.002 & $(0.001)$ & $* * *$ & & & & & & \\
\hline Reincarnation & & & & & & & -0.001 & $(0.000)$ & $* * *$ & & & \\
\hline Simple life & & & & & & & & & & 0.039 & $(0.012)$ & $* * *$ \\
\hline Observations & 1173 & & & 1173 & & & 1173 & & & 1173 & & \\
\hline Pseudo R-squared & 0.151 & & & 0.156 & & & 0.157 & & & 0.159 & & \\
\hline Log likelihood & -644.6 & & & -640.4 & & & -640.1 & & & -638.8 & & \\
\hline
\end{tabular}

Note: The reported results are marginal effects. The figures in brackets are standard errors. ${ }^{* * *} \mathrm{p}<0.01,{ }^{* *} \mathrm{p}<0.05$, and ${ }^{*} \mathrm{p}<0.1$. 
Table 5. Blinder-Oaxaca decomposition results for the differences in spoiling love between Turkish people in Germany and Turkish people in Turkey

\begin{tabular}{|c|c|c|c|c|c|c|c|c|c|c|c|c|}
\hline & (1) & & & 2) & & & 3) & & & (4) & & \\
\hline Religious & 0.056 & $(0.011)$ & *** & 0.048 & $(0.012)$ & $* * *$ & 0.050 & $(0.012)$ & *** & 0.048 & $(0.012)$ & *** \\
\hline Age & 0.002 & $(0.002)$ & & 0.002 & $(0.002)$ & & 0.002 & $(0.002)$ & & 0.003 & $(0.002)$ & \\
\hline Education & -0.004 & $(0.008)$ & & -0.002 & $(0.008)$ & & -0.002 & $(0.008)$ & & -0.002 & $(0.008)$ & \\
\hline Impatience & 0.005 & $(0.004)$ & & 0.005 & $(0.004)$ & & 0.005 & $(0.004)$ & & 0.004 & $(0.004)$ & \\
\hline Debt aversion & -0.002 & $(0.002)$ & & -0.002 & $(0.002)$ & & -0.002 & $(0.002)$ & & -0.002 & $(0.002)$ & \\
\hline Income & -0.023 & $(0.023)$ & & -0.025 & $(0.022)$ & & -0.019 & $(0.024)$ & & -0.023 & $(0.023)$ & \\
\hline Spiritually directed confidence & -0.046 & $(0.034)$ & & -0.054 & $(0.033)$ & & -0.046 & $(0.035)$ & & -0.043 & $(0.035)$ & \\
\hline Nonspiritually directed confidence & 0.110 & $(0.053)$ & ** & 0.102 & $(0.052)$ & ** & 0.104 & $(0.052)$ & ** & 0.107 & $(0.052)$ & ** \\
\hline Evolution & & & & 0.082 & $(0.027)$ & *** & & & & & & \\
\hline Reincarnation & & & & & & & 0.042 & $(0.016)$ & *** & & & \\
\hline Simple life & & & & & & & & & & 0.020 & $(0.007)$ & *** \\
\hline Number of observations & 1209 & & & 1209 & & & 1209 & & & 1209 & & \\
\hline Number of observations ( $\mathrm{G}=1$, Turkey) & 1065 & & & 1065 & & & 1065 & & & 1065 & & \\
\hline Number of observations $(\mathrm{G}=1$, Germany) & 144 & & & 144 & & & 144 & & & 144 & & \\
\hline $\begin{array}{l}\text { Prob(Dependent variable }=0 \mid \text { Germany dummy }= \\
0 \text { ) }\end{array}$ & 0.726 & & & 0.726 & & & 0.726 & & & 0.726 & & \\
\hline Prob(Dependent variable | Germany dummy = 1) & 0.132 & & & 0.132 & & & 0.132 & & & 0.132 & & \\
\hline Difference & 0.595 & & & 0.595 & & & 0.595 & & & 0.595 & & \\
\hline Total explained & 0.098 & & & 0.156 & & & 0.135 & & & 0.112 & & \\
\hline Percentage of total explained & $17 \%$ & & & $26 \%$ & & & $23 \%$ & & & $19 \%$ & & \\
\hline
\end{tabular}


Figure 1. Frequency distribution of the answers to the hypothetical fever question

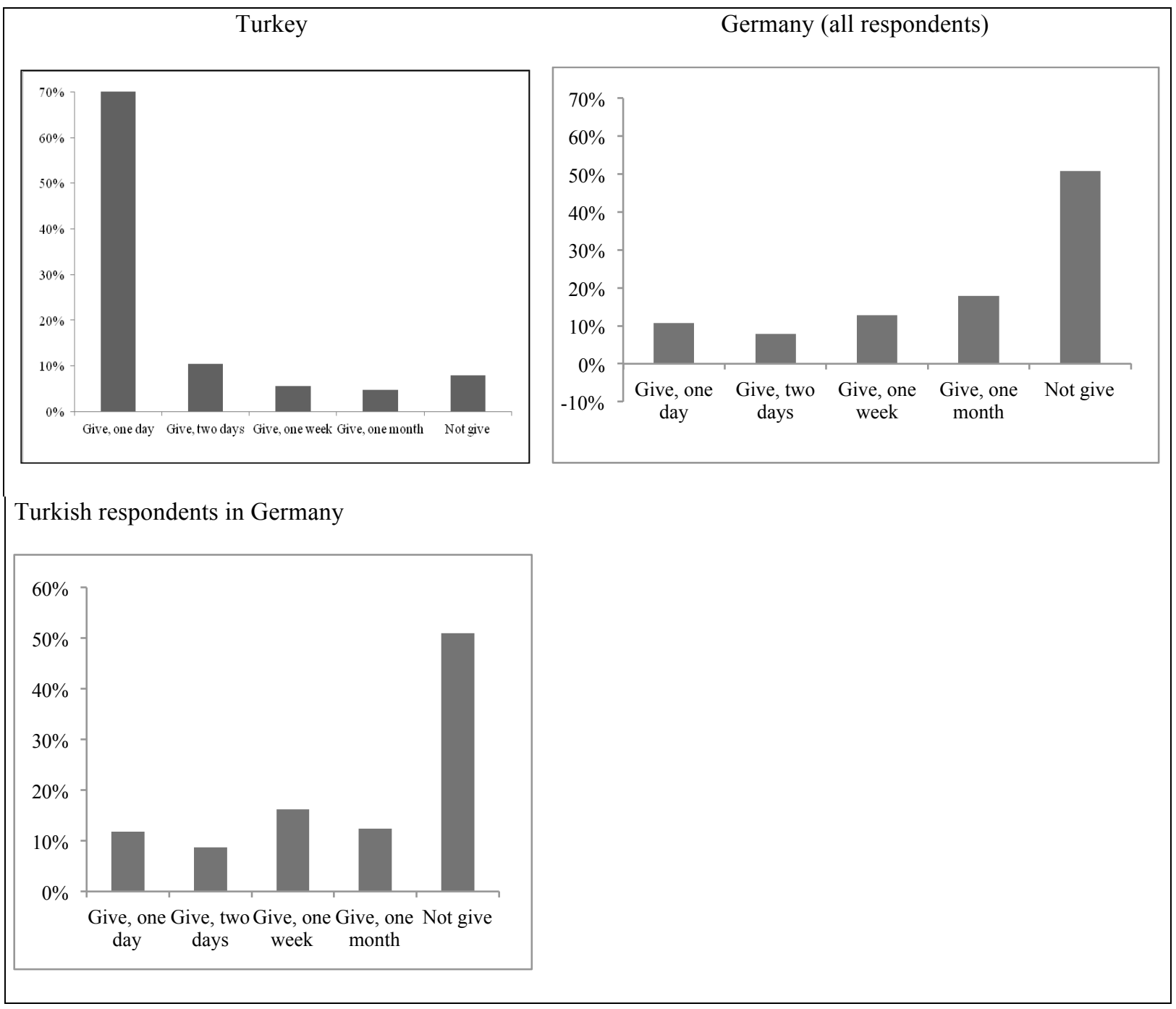

Figure 2. Frequency distribution for Turkish respondents in Germany, and years of residence in Germany

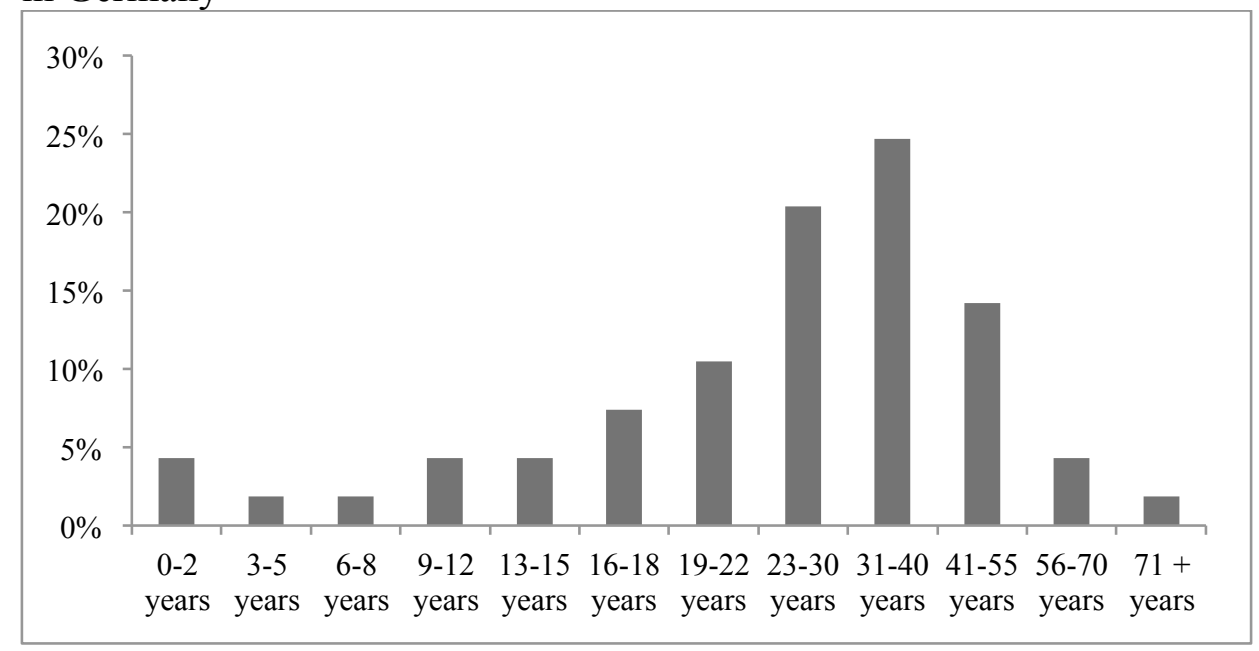


Figure 3. Frequency distributions of the spiritually directed confidence variable

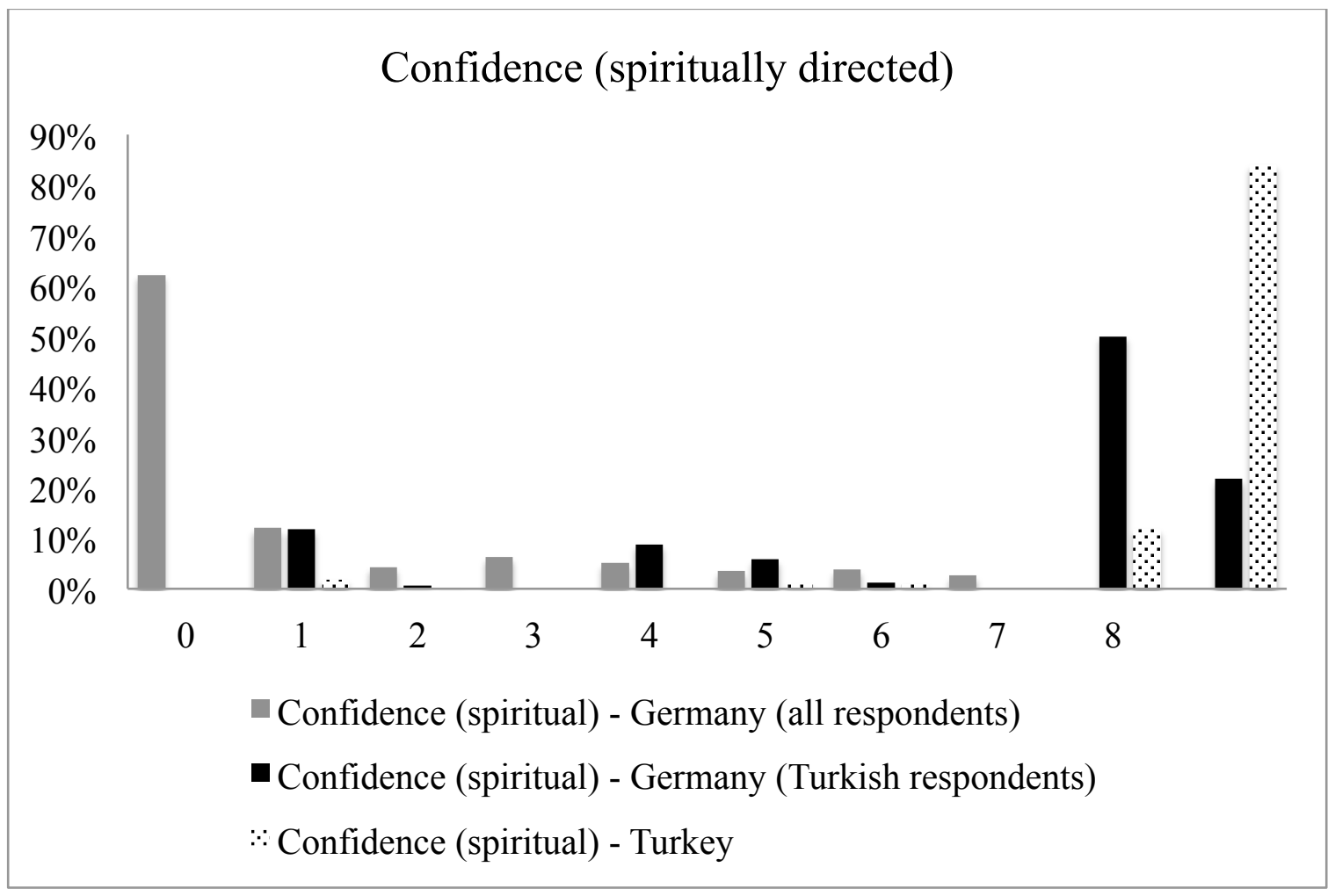

Figure 4. Frequency distributions of the nonspiritually directed confidence variable

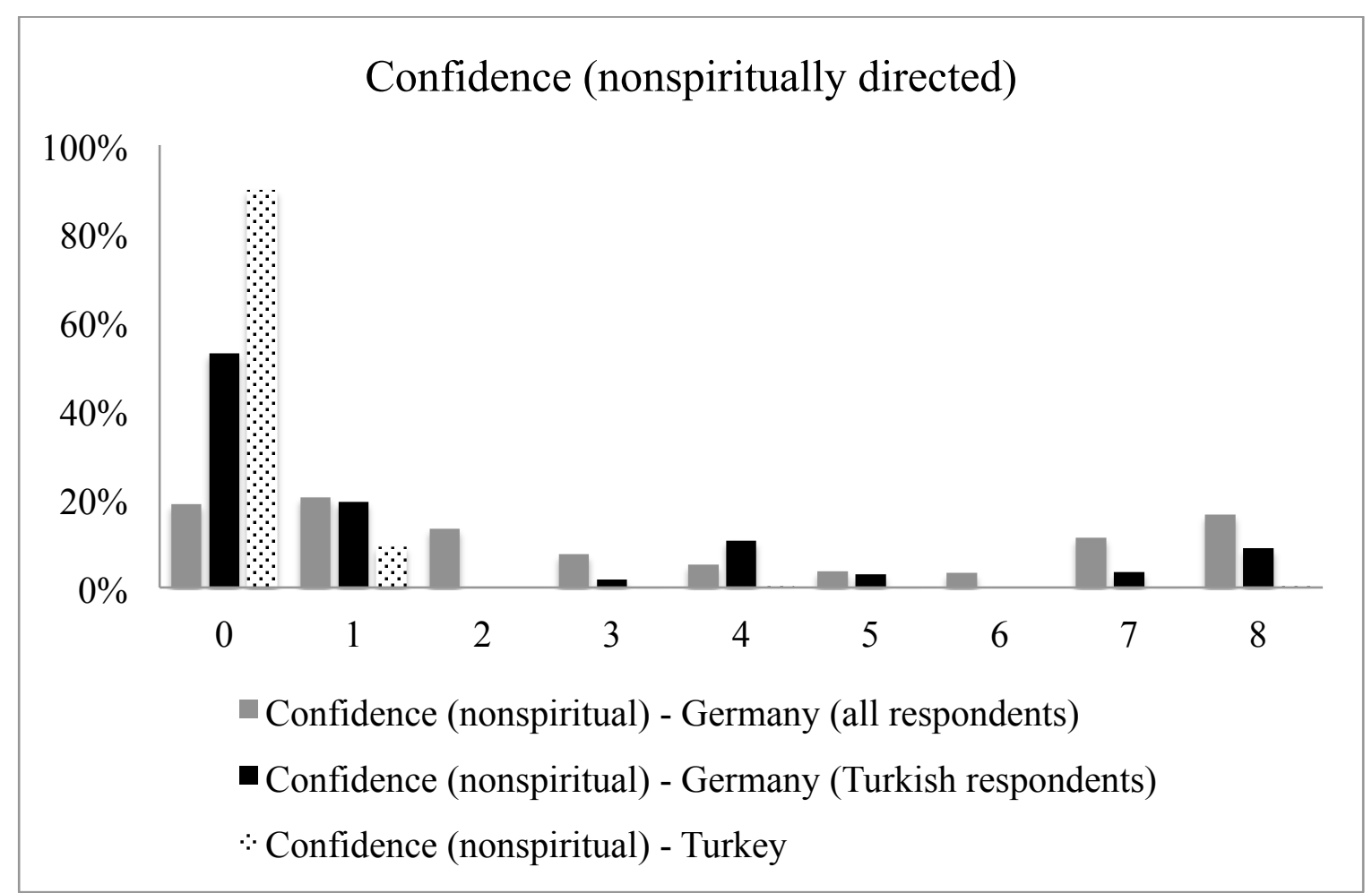

